\title{
Type III atresia coli with underdeveloped colon and hydroperitoneum in a newborn foal
}

\author{
Izabela de Assis Rocha ${ }^{1^{*}}$ Jéssica Guerra de Oliveira ${ }^{2}$ (D) Tatiana de Carvalho Castro ${ }^{3}$ (D) \\ Tâmiles Naiara dos Santos Bispo ${ }^{\mathbb{D}}$ Sóstenes Apolo Correia Marcelino ${ }^{5}$ \\ Marco Túlio Gomes Campos ${ }^{2}$ Felipe Pierezan ${ }^{6}$ iD \\ Paulo Ricardo de Oliveira Paes ${ }^{6}$ (D) Raffaella Bertoni Cavalcanti Teixeira ${ }^{6}$ iD \\ Maristela Silveira Palhares ${ }^{6}$ Denata de Pino Albuquerque Maranhão ${ }^{6}$ D
}

\author{
${ }^{1}$ Department of Veterinary Science, University of Kentucky (UK), 40546-0099, Lexington, Kentucky (KY), United States of America (USA) \\ E-mail: izabela.idar@uky.edu. "Corresponding author. \\ ${ }^{2}$ Programa de Pós-Graduação em Ciência Animal, Área de Concentração em Medicina e Cirurgia Veterinárias, Escola de Veterinária, \\ Universidade Federal de Minas Gerais (UFMG), Belo Horizonte, MG, Brasil. \\ ${ }^{3}$ Regimento de Polícia Montada 9 de Julho, Polícia Militar do Estado de São Paulo (PMESP), SP, São Paulo, Brasil. \\ ${ }^{4}$ Médica Veterinária Autônoma, CRMV-BA n ${ }^{\circ} 4701$, Simões Filho, BA, Brasil. \\ ${ }^{5}$ Programa de Pós-Graduação em Ciência Animal, Área de Concentração em Patologia Animal, Escola de Veterinária, Universidade Federal de \\ Minas Gerais (UFMG), Belo Horizonte, MG, Brasil. \\ ${ }^{6}$ Departamento de Clínica e Cirurgia Veterinárias, Escola de Veterinária, Universidade Federal de Minas Gerais (UFMG), Belo Horizonte, MG, Brasil.
}

ABSTRACT: A 48-hour-old mixed breed pony colt was referred to the hospital because of abdominal discomfort, weak suckling reflex and prostration. During clinical investigation, supportive and symptomatic treatments were necessary, and an abdominal radiography was performed revealing a large intestine filled with feces and large amounts of gas, in addition to free fluid in the cavity. After 3 days of treatment, the foal had not yet defecated, thus exploratory abdominal surgery was indicated, but the owners declined. Therefore, the foal was humanly euthanized. Post-mortem examination revealed complete absence of the pelvic flexure. Subsequent portions of the dorsal, transverse and small colons were intensely reduced. In addition, at the abdominal cavity there was $850 \mathrm{ml}$ of yellowish translucent liquid. These findings are compatible with hydroperitoneum and type III atresia coli at the pelvic flexure, associated with underdevelopment of the dorsal, transverse and small colons.

Key words: colic, neonatology, congenital malformation.

Atresia coli tipo III com subdesenvolvimento de cólon e hidroperitôneo em neonato equino

RESUMO: Um pônei mestiço de 48 horas de vida foi encaminhado ao hospital para avaliação por desconforto abdominal, diminuição do reflexo de sucção e prostração. Durante a investigação clínica, tratamentos de suporte e sintomáticos foram necessários, e radiografia abdominal foi realizada revelando cólon maior repleto de fezes e grandes quantidades de gás, além de fluido livre na cavidade. Após três dias de tratamento, o potro ainda não havia defecado, sendo a laparotomia exploratória indicada, mas os proprietários recusaram. Portanto, o potro foi humanamente eutanasiado. $O$ exame post-mortem revelou ausência completa da flexura pélvica. Porções subseqüentes dos cólons dorsal, cólon transverso e cólon menor se apresentaram intensamente reduzidas. Além disso, na cavidade abdominal havia 850 ml de líquido translúcido amarelado. Esses achados são compativeis com o hidroperitônio e a atresia coli tipo III na flexura pélvica, associados ao subdesenvolvimento dos cólons dorsal, transverso e menor.

Palavras-chave: cólica, neonatologia, má-formação congênita.

Abdominal pain in foals is a diagnostic challenge; therefore, a good physical examination is critical when assessing a colicky foal (BOHANON, 2005). Colic starting at birth or shortly thereafter can be caused by meconium impaction, uroperitoneum or fecoliths, and also congenital disorders such as atresia coli, aganglionosis and hypoganglionosis (CHAFFIN et al., 1999; BOHANON, 2005).
Since physical examination has limitations to differentiate between surgical and non-surgical lesions, complementary exams are paramount. Peritoneal fluid analysis, nasogastric intubation, radiography and ultrasonography are indicated. Since rectal examination is not possible in young foals, abdominal radiography is very useful to access gas distention and the use of contrast allows better 
evaluation of obstructions. Ultrasonography provides information on gas distention, fluid accumulation and intussusception (BOHANON, 2005).

Intestinal atresia should be suspected when there is no fecal material on the anus, with presence of clear mucus, absence of meconium staining following repeated enemas, progressive abdominal distention and pain on a neonate (YOUNG et al., 1992; VATISTAS et al., 1996; CHAFFIN et al., 1999; BIASUTTI et al., 2017). It is a rare cause of colic that affects $0.44-3.1 \%$ of the equine neonates within the first $24-48 \mathrm{~h}$ of life, resembling meconium impaction (BARTMANN et al., 2002; BIASUTTI et al., 2017). There are three types of atresia: type $\mathrm{I}$ is a membrane atresia, when there is a complete diaphragm obstructing the intestinal lumen, type II is a cord atresia, with blind ends of intestine joined by a fibrous and/or muscular cord, and type III is a blindend atresia, characterized by a complete absence of an intestinal segment with a gap in the mesentery, accompanied by short bowel. It is believed that atresia coli is caused by a persistent occlusion of blood supply during the formation of the intestine (VAN DER GAAG et al., 1980). Foals with atresia coli often have congenital anomalies in other organs, and these abnormalities should be investigated before attempting surgery (BARTMANN et al., 2002). Successful surgical repair is rare, but it has been described (SCHNEIDER et al., 1981; NAPPERT et al., 1992; BIASUTTI et al., 2017). In light of those considerations, the aim of this report was to describe the clinical and post-mortem features of colic in a newborn foal with colonic sub development.

A 48-h-old mixed breed pony colt foal was referred to the veterinary teaching hospital for assessment of abdominal discomfort, weak suckling reflex and prostration. Owners reported the foal stood and nursed shortly after birth but had a weak suckling reflex. The foal was observed to urinate and pass meconium in the first 24 hours, but a few hours later it started showing abdominal pain. Local veterinarian was called, who decided to refer it to a hospital after performing the enema unsuccessfully on property.

On presentation, the foal was lethargic and rolling, with moderate abdominal distention. Vital signs were as follow: temperature $38.7^{\circ} \mathrm{C}$, heart rate 140 beats/minute, respiratory rate 54 breaths/ minute, capillary refill time 2 seconds, and hyperemic mucous membranes. Auscultation of heart and lungs did not detect any abnormalities. Borborygmi were decreased, without any sound of ileocecal valve for 5 minutes. On digital rectal exam, only clear mucus was observed, without typical brown staining from meconium. Urine was concentrated and the foal constantly assumed a ventroflexed position with the limbs stretched out.

Laboratory work included a complete blood count and blood chemistry analysis (Table 1). Plasma was icteric, with hyperfibrinogenemia, neutrophilia and lymphopenia. There were hyper segmented and toxic neutrophils, activated monocytes and platelet aggregation. AST was below normal range; ALP was above normal limits and there was hypoproteinemia with low globulins.

Transabdominal ultrasound was performed using a 5-MHz transducer. Small intestinal loops with normal wall thickness were observed, as well as small volume of peritoneal fluid and a mass near the ventral wall suggestive of impaction. Bladder was partially full and apparently intact. Abdominocentesis was not performed at this point due to the risk of enterocentesis.

During clinical investigation, supportive and symptomatic treatments were necessary and are described as follows. Initially, pain was moderate and controlled with flunixin meglumine ${ }^{(a)}(1.1 \mathrm{mg} / \mathrm{kg}$ IV q. $8 \mathrm{~h}$ in the first $24 \mathrm{~h}$ and then when necessary) and short walks. Symptomatic treatment included ranitidine $^{(\mathrm{b})}\left(2 \mathrm{mg} / \mathrm{kg}\right.$ IV TID), penicillin ${ }^{(\mathrm{c})}$ (22000UI/ $\mathrm{kg}$ IM SID), gentamicin ${ }^{(\mathrm{d})}(6.6 \mathrm{mg} / \mathrm{kg}$ IV SID) and ceftiofur $^{(\mathrm{e})}\left(4.4 \mathrm{mg} / \mathrm{kg}\right.$ IM BID). Omeprazole ${ }^{(\mathrm{f})}$ were administered once at a dosage of $4 \mathrm{mg} / \mathrm{kg}$ PO. Frequent enemas with Vaseline ${ }^{(\mathrm{g})}$ and warm water and stomach decompression via nasogastric tube were performed until presumptive diagnosis was reached. It is known that duodenal distention and reflux can cause abdominal distention in foals. Enemas were followed by clear mucus elimination, which was highly suggestive of atresia coli. Therapy with antibiotics was elected based on complete blood count, which was suggestive of sepsis. Central venous catheter was placed in the jugular vein and fluid therapy was instituted based in the Holliday-Seagar formula with Ringer's lactate solution supplemented with glucose $5 \%$ and potassium.

At the end of day 1 of hospitalization, the foal had not yet defecated, and enemas resulted in clear mucus, without feces in the rectum. Urine was diluted and abundant. Since there was no reflux at this point and the foal manifested interest in nursing, nasogastric tube was removed, allowing the foal to nurse and walk every hour. Blood glucose levels remained around $130-180 \mathrm{mg} / \mathrm{dL}$.

On day 2, abdominal distention was intense, and the foal had stopped nursing. Nasogastric tube was placed again, recovering $1 \mathrm{~L}$ of spontaneous 
Table 1 - Hematological and biochemical profile of a 48-hour-old foal diagnosed with atresia coli type III at the Veterinary Hospital of the Universidade Federal de Minas Gerais, Brazil.

\begin{tabular}{|c|c|c|}
\hline \multicolumn{2}{|c|}{-----Plasma physical appearance: discretely icteric---- } & Colorless to light yellow plasma \\
\hline Fibrinogen & $600 \mathrm{mg} / \mathrm{dL}$ & $100-400 \mathrm{mg} / \mathrm{dL}$ \\
\hline Red blood cells & $9.05 \mathrm{million} / \mathrm{mm}^{3}$ & $6.6-11 \mathrm{million} / \mathrm{mm}^{3}$ \\
\hline Hemoglobin & $14 \mathrm{~g} / \mathrm{dL}$ & $11-16 \mathrm{~g} / \mathrm{dL}$ \\
\hline Hematocrit & $40 \%$ & $30-44 \quad \%$ \\
\hline $\mathrm{MCV}$ & $44.2 \mathrm{fL}$ & $38-51 \mathrm{fL}$ \\
\hline $\mathrm{MCHC}$ & $35 \%$ & $35-39 \%$ \\
\hline $\mathrm{MCH}$ & $15.47 \mathrm{pg}$ & $13-19 \mathrm{pg}$ \\
\hline Total leucocytes & $8.450 / \mathrm{mm}^{3}$ & $5.600-11.600 / \mathrm{mm}^{3}$ \\
\hline Neutrophils & $90 \%\left(7.605 / \mathrm{mm}^{3}\right)$ & $2.600-6.700 / \mathrm{mm}^{3}$ \\
\hline Lymphocytes & $7 \%\left(591.5 / \mathrm{mm}^{3}\right)$ & $1.100-5.700 / \mathrm{mm}^{3}$ \\
\hline Monocytes & $3 \%\left(253.5 / \mathrm{mm}^{3}\right)$ & $0-700 / \mathrm{mm}^{3}$ \\
\hline Platelets & $298.000 / \mathrm{mm}^{3}$ & $100.000-308.000 / \mathrm{mm}^{3}$ \\
\hline \multicolumn{3}{|c|}{ BLOOD SMEAR EVALUATION: } \\
\hline \multicolumn{3}{|c|}{ It was observed the presence of: Toxic neutrophils, hyper segmented neutrophils, activated monocytes and platelet aggregates. } \\
\hline \multicolumn{3}{|c|}{$\begin{array}{l}{ }^{1} \text { Reference: } \\
\text { HARVEY, J. W. Veterinary Hematology: A Diagnostic Guide and Color Atlas. St. Louis: Elsevier/Saunders, } 2012 .\end{array}$} \\
\hline \multicolumn{2}{|c|}{---------------BLOOD BIOCHEMISTRY------------- } & 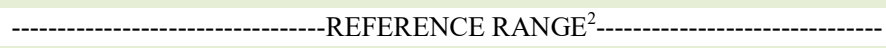 \\
\hline Urea & $48.69 \mathrm{mg} / \mathrm{dL}$ & $21.4-51.5 \mathrm{mg} / \mathrm{dL}$ \\
\hline Creatinine & $1.12 \mathrm{mg} / \mathrm{dL}$ & $0.4-2.2 \mathrm{mg} / \mathrm{dL}$ \\
\hline ALT & $9.97 \mathrm{U} / \mathrm{L}$ & $3-23 \mathrm{U} / \mathrm{L}$ \\
\hline AST & $190.78 \mathrm{U} / \mathrm{L}$ & $226-366 \mathrm{U} / \mathrm{L}$ \\
\hline ALP & $1107 \mathrm{U} / \mathrm{L}$ & $86-295 \mathrm{U} / \mathrm{L}$ \\
\hline GGT & $26.1 \mathrm{U} / \mathrm{L}$ & $6-32 \mathrm{U} / \mathrm{L}$ \\
\hline Glucose & $35 \mathrm{mg} / \mathrm{dL}$ & $62-134 \mathrm{mg} / \mathrm{dL}$ \\
\hline Total protein & $3.96 \mathrm{~g} / \mathrm{dL}$ & $6-8 \mathrm{~g} / \mathrm{dL}$ \\
\hline Albumin & $2.51 \mathrm{~g} / \mathrm{dL}$ & $2.4-4.1 \mathrm{~g} / \mathrm{dL}$ \\
\hline Globulins & $1.45 \mathrm{~g} / \mathrm{dL}$ & $2.6-4 \mathrm{~g} / \mathrm{dL}$ \\
\hline${ }^{2}$ Reference: & & \\
\hline MEYER, D. & ório veterin & terpretação e diagnóstico. São Paulo: Roca, 1995. \\
\hline
\end{tabular}

reflux. Blood gas and electrolytes analysis revealed low oxygen saturation with an increase in bicarbonate and decrease in anion gap (Table 2). Reflux stopped at the end of the day. In order to protect gastric mucosa and to help reduce abdominal distention, a solution ${ }^{(h)}$ containing aluminum hydroxide, magnesium hydroxide and simethicone was administered, and nasogastric tube was removed again. Initially, several attempts to feed the foal were made before complete food withdraw due to worsening of abdominal distension. Nasogastric tube was placed once again, and all the nursed milk recovered. At this point, blood glucose dropped to $80 \mathrm{mg} / \mathrm{dL}$ and remained on this level. Abdominal radiography was performed on day 3 , revealing a large intestine filled with feces and large amounts of gas, in addition to free fluid in the cavity (Figures 1 and 2). Peritoneal fluid sample was referred to the laboratory with a paired serum sample. Both peritoneal fluid and serum samples were with normal range for equine species (GRINDEM et al., 1990). Based on the results, uroperitoneum was excluded from the differential diagnosis and presumptive diagnosis was complete intestinal obstruction, probably due to meconium impaction. Due to the presence of nasogastric reflux and the possibility of meconium impaction with distention, contrast radiography was not performed nor orally neither via rectum. Also, due to worsening of the clinical status and financial restraints, no further diagnostic procedures were made. Although 
Table 2 - Blood gas and electrolyte profile of a 48-hour-old foal diagnosed with atresia coli type III at the Veterinary Hospital of the Universidade Federal de Minas Gerais, Brazil.

\begin{tabular}{|c|c|c|}
\hline & & REFERENCE RANGE $^{3}$ \\
\hline $\mathrm{pH}$ & 7.432 & $7.32-7.44$ \\
\hline $\mathrm{pCO} 2$ & $46.3 \mathrm{mmHg}$ & $38-46 \mathrm{mmHg}$ \\
\hline $\mathrm{pO} 2$ & $61.3 \mathrm{mmHg}$ & $63-77 \mathrm{mmHg}$ \\
\hline $\mathrm{sO} 2$ & $87.5 \%$ & $92-96 \%$ \\
\hline $\mathrm{cK}+$ & $3.2 \mathrm{mM}$ & $2.4-4.7 \mathrm{mM}$ \\
\hline $\mathrm{cNa}+$ & $142 \mathrm{mM}$ & $132-146 \mathrm{mM}$ \\
\hline cCl- & $109 \mathrm{mM}$ & $99-109 \mathrm{mM}$ \\
\hline cHCO3-(P)c & 30.3 & $20-28$ \\
\hline cBase(B)c & $5.5 \mathrm{mM}$ & $3.51-9.39 \mathrm{mM}$ \\
\hline AnionGap K+ & $5.9 \mathrm{mM}$ & $12.08-16.62 \mathrm{mM}$ \\
\hline cLac & 1.6 & $1.1-2.3$ \\
\hline
\end{tabular}

CARLUCCIO, A. et al. Correlation between some arterial and venous blood gas parameters in healthy newborn Martina Franca donkey foals from birth to 96 hours of age. Theriogenology. v.87, p.173-178, 2017. Available from: <https:/www.ncbi.nlm.nih.gov/pubmed/27667749>. Accessed: Nov. 13, 2019. doi: 10.1016/j.theriogenology.2016.08.021.

CASTAGNETTI, C. et al. Venous blood lactate evaluation in equine neonatal intensive care. Theriogenology, v.73, n.3, p.343-357, 2010. Available from: <https://www.ncbi.nlm.nih.gov/pubmed/19962183>. Accessed: Nov. 13, 2019. doi: 10.1016/j.theriogenology.2009.09.018.

CRUZ, R. K. S. et al. Electrolyte, blood gas and electrocardiographic profile of neonatal foals in the first 48 hours of life. Acta Scientiae Veterinariae. v.43, p.1321-1327, 2015. Available from: <http://www.ufrgs.br/actavet/43/PUB\%201321>. Accessed: Nov. 13, 2019.

HUGLES, J.; BARDELL, B. Determination of reference intervals for equine arterial blood-gas, acid-base and electrolyte analyses. Veterinary Anesthesia and Analgesia, v.46, n.6, p.765-771, 2019. Available from: <https:/www.vaajournal.org/article/S14672987(19)30141-2/fulltext>. Accessed: Nov. 13, 2019. doi: 10.1016/j.vaa.2019.04.015.

KANEKO, J. J.; BRUSS, M. L. Bioquímica Clínica de Animais Domésticos. San Diego: Academic Press, 1997.

bowel sounds and mucous membranes have shown improvement with medical treatment, the foal had not yet defecated until that moment. Exploratory abdominal surgery was also declined by the owners. Thus, after $60 \mathrm{~h}$ of medical management, the foal was humanely euthanized.

Post-mortem examination revealed absence of the pelvic flexure, associated with marked accumulation of meconium in the cecum and on the blind ending sac in the left ventral colon. Subsequent portions of the dorsal colons, transverse colon and small colon were intensely reduced. In its lumen, there was a slight accumulation of mucous contents. In addition, mucous membranes were discretely yellowish and in the abdominal cavity there were 850 $\mathrm{ml}$ of yellowish translucent liquid. These findings are compatible with hydroperitoneum and type III atresia coli at the pelvic flexure, associated with underdevelopment of the dorsal, transverse and small colons (Figure 3).

Colic in foals is a common condition and a diagnostic challenge. Normal meconium passage starts shortly after birth and continues for the first 24h (BOHANON, 2005). Since meconium impaction is the most common cause of obstruction and colic in foals, it was the first suspicion on the differential diagnostic list for the foal here reported. It is possible that owners may have observed the passage of a small amount of meconium formed in the most caudal portions of the intestine, since all the remaining meconium was accumulated cranially to the atresia coli.

Despite the fact that uroperitonium does not lead to obstruction, it was considered a possibility, once the patient showed strangury with ventroflexed posture and limbs stretched out. However, the foal urinated large volumes, while abdominal ultrasound did not show enough free fluid in the abdominal cavity and bladder was intact. Later, after laboratory analysis, free fluid in the abdomen seen in radiographs was not considered urine. Fecaliths were considered another possible cause of gastrointestinal obstruction without vascular impairment. Based on this suspicion, surgical intervention would have both 


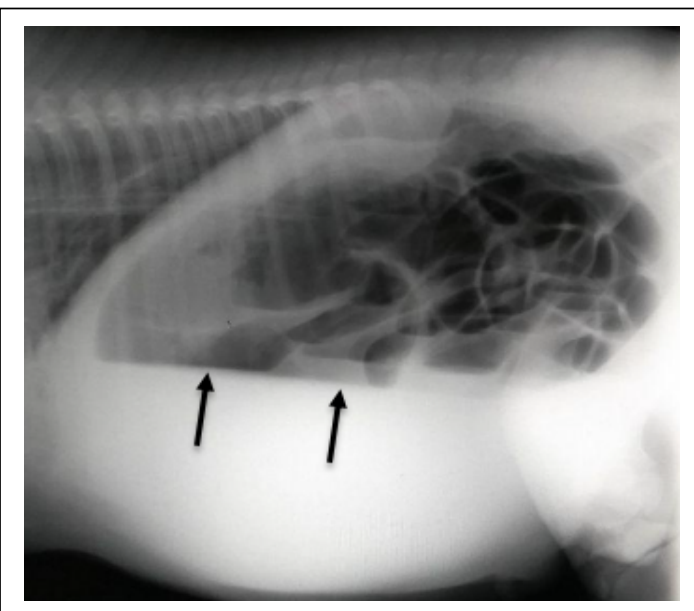

Figure 1 - Latero-lateral radiography showing a large amount of free fluid (black arrows) in the abdominal cavity of a 96-hour old pony foal diagnosed with atresia coli type III at the Veterinary Hospital of the Universidade Federal de Minas Gerais, Brazil.

diagnostic and therapeutic value (CHAFFIN et al., 1999; BOHANON, 2005).

Although rare, atresia coli was another probable cause of obstruction; yet the presence of

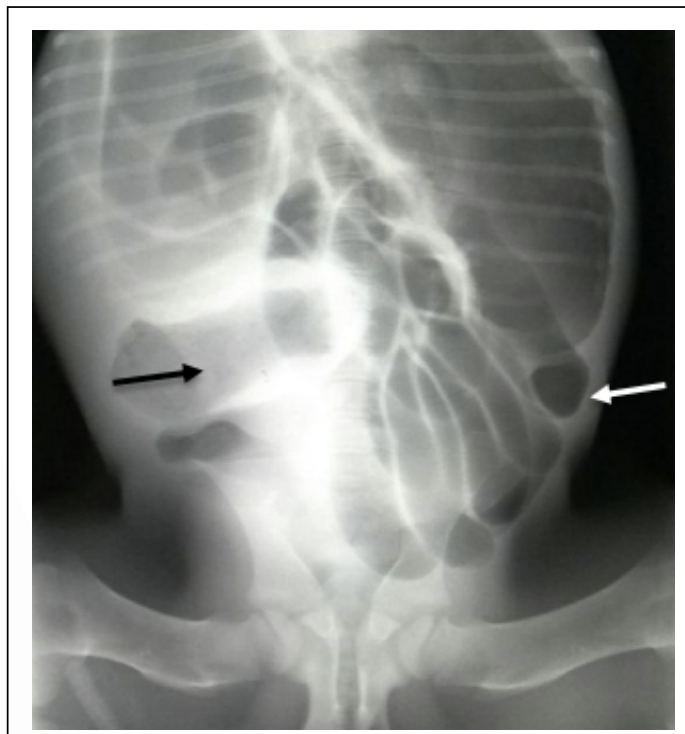

Figure 2 - Ventrodorsal radiography showing intestines filled with feces (black arrow) and gas (white arrow) in the abdominal cavity of a 96hour old pony foal diagnosed with atresia coli type III at the Veterinary Hospital of the Universidade Federal de Minas Gerais, Brazil. nasogastric reflux did not allow oral administration of barium solutions to perform contrast radiography. It should be acknowledged that the use of contrast rectally could have confirmed diagnosis ante mortem. However, the possibility of meconium impaction and further distention of the rectum was our main concern. Also, the worsening of clinical signs and financial restraint limited additional diagnostic procedures. Atresia coli would have been diagnosed anyway should the owners have decided for exploratory laparotomy. Even though, medical treatment was still attempted until other probable causes were excluded or exploratory surgery authorized.

Complete blood count in this case was suggestive of sepsis and hypoproteinemia indicated that a failure of passive immunity might have occurred. Nevertheless, our foal did not manifest clinical signs consistent with sepsis. Abdominal ultrasound and radiographs were highly suggestive of a gastrointestinal obstruction, and we hypothesized this obstruction was the cause of both the inflammatory status seen in the laboratory analyses and hydroperitonium.

Since the patient showed no improvement with medical therapy and the owners declined surgery, euthanasia was recommended. Yellowish mucous membranes were attributed to the inability to feed the

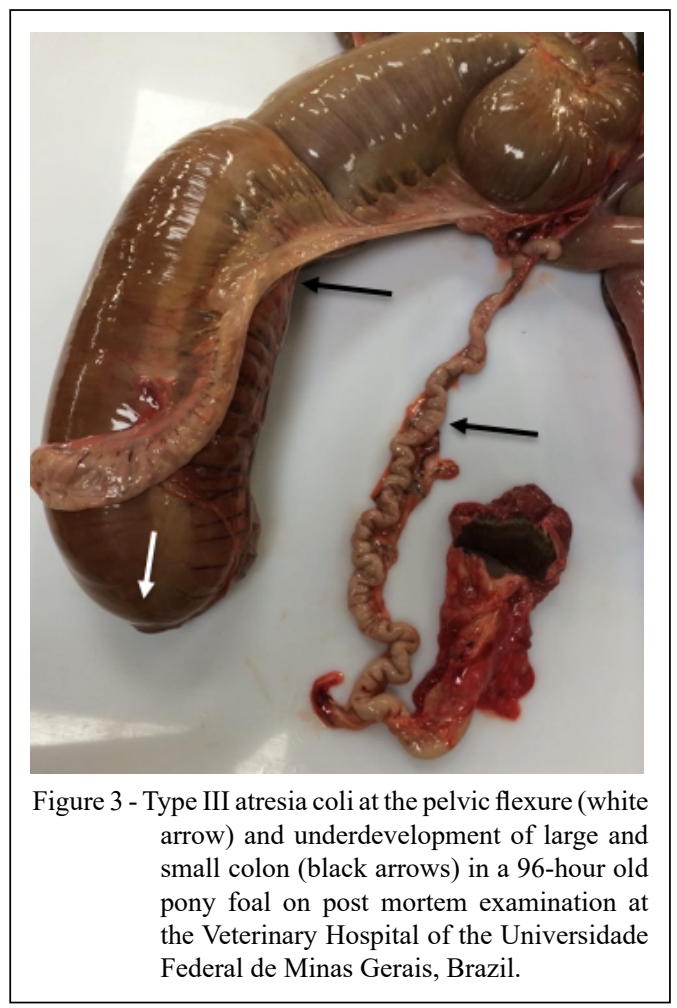

Ciência Rural, v.50, n.10, 2020. 
foal, since every attempt was followed by worsening of abdominal distention and need of nasogastric intubation. Hydroperitoneum was likely due to hypoproteinemia and abdominal inflammation. It is important to observe that this foal had two congenital abnormalities in the colon: type III atresia coli at the pelvic flexure and hypoplasia of the large colon caudal to the atresia. Considering this situation, the odds of a successful surgical intervention were minimal.

Although atresia coli is a rare condition in foals, it must be considered when dealing with a newborn foal with abdominal pain and distension. Clinicians should pay special attention when colic resembling meconium impaction responds poorly to medical management, especially if there is no brown staining after repeated enemas and no clinical signs that suggest strangulating intestinal lesions.

\section{ACKNOWLEDGEMENTS}

This project was financed in part by the Coordenação de Aperfeiçoamento de Pessoal de Nível Superior (CAPES), Brasil Finance code 001. We thank the Ministério da Educação (MEC) for financing the Multiprofessional Residency at UFMG, which allowed the participation of I.A. ROCHA, J.G. OLIVEIRA, T.C. CASTRO, T.N.S. BISPO, S.A.C. MARCELINO and M.T.G. CAMPOS in this project.

\section{SOURCES AND MANUFACTURERS}

${ }^{a}$ Flumax ${ }^{\circledR}$ (flunixim meglumine). Made and commercialized by J.A. Saúde Animal. Travessa José Coelho de Freitas, 1712. Patrocínio Paulista - SP. Centro - CEP 14.415-000.

${ }^{b}$ Ranitidina ${ }^{\circledR}$ (ranitidine chloride). Made and commercialized by Hypofarma. Rua Dr. Irineu Marcellini, 303. Bairro São Geraldo. Ribeirão das Neves - MG. CEP 33850-330.

${ }^{\mathrm{c} A g r o s i l ~} 6^{\circledR}$ (commercial solution containing Penicillin procaine, Penicillin potassium, and Penicillin benzathine). Made and commercialized by Vansil Saúde Animal. Rua João Augusto Cirelli, 640. Descalvado - SP, CEP 13690-000.

${ }^{\mathrm{d} P a n g r a m} 10 \%{ }^{\circledR}$ (gentamicin). Made and commercialized by Virbac. Avenida Queiroz Filho, 1560 - Vila Leopoldina, São Paulo - SP, CEP 05317-000.

${ }^{\mathrm{e}} \mathrm{CEF} 50^{\circledR}$ (ceftiofur). Made and commercialized by Agener União. Avenida Magalhães de Castro, 4800. $16^{\circ}$ Andar - Conjuntos 161 e 162. Edifício Continental Tower 05676-120/São Paulo - SP

${ }^{\mathrm{f}}$ Omeoprazol 8,5\% ${ }^{\circledR}$ (omeprazole). Made and commercialized by DrogaVet. Avenida do Contorno, 7449. Bairro Santo Antônio. Belo Horizonte - MG. CEP 30410-210.

${ }^{g}$ Vaselina sólida ${ }^{\circledR}$ (solid vaseline). Made and comercialized by Rioquimica. Avenida Tarraf, 2.600 - São José do Rio Preto - SP. CEP 15057-441.

${ }^{\mathrm{h}}$ Simeco plus ${ }^{\circledR}$ (commercial solution containing aluminum hydroxide, magnesium hydroxide and simethicone). Made and commercialized by Eurofarma Laboratórios/S.A. Avenida Vereador José Diniz, 3.465 - São Paulo - SP. CNPJ: 61.190.096/0001-92.

\section{DECLARATION OF CONFLICT OF INTERESTS}

The authors declare no conflict of interest. The founding sponsors had no role in the design of the study; in the collection, analyses, or interpretation of data; in the writing of the manuscript, and in the decision to publish the results.

\section{AUTHORS' CONTRIBUTIONS}

All authors contributed equally for the conception and writing of the manuscript. All authors critically revised the manuscript and approved of the final version.

\section{REFERENCES}

BARTMANN, C.P. et al. Diagnosis and surgical management of Colic in the Foal: Literature Review and a Retrospective Study. Clinical Techniques in Equine Practice, v.1, n.3, p.125-142, 2002. Available from: <https://www.sciencedirect.com/science/ article/pii/ S1534751602800117>. Accessed: Jun. 24, 2019. doi: 10.1053/ctep.2002.35574.

BIASUTTI, S. et al. End-to-side anastomosis of the left ventral colon to the small colon in a neonatal foal with segmental agenesis of the large colon. Australian Veterinary Journal, v.95, n.6, p.217-219, 2017. Available from: <https://onlinelibrary.wiley.com/ doi/abs/10.1111>. Accessed: Jun. 24, 2019.

BOHANON, C.T. Colic in the equine neonate. In: North American Veterinary Conference, 2005, Orlando, United States of America. Proceedings... Orlando: NAVC, 2005. p.129131. Online. Available from: <https://pdfs.semanticscholar.org/ b80b/4662cfc87da432f528a29cc $>$.

CARLUCCIO, A. et al. Correlation between some arterial and venous blood gas parameters in healthy newborn Martina Franca donkey foals from birth to 96 hours of age. Theriogenology. v.87, p.173-178, 2017. Available from: <https:/www.ncbi.nlm.nih. gov/pubmed/27667749>. Accessed: Nov. 13, 2019. doi: 10.1016 /j.theriogenology.2016.08.021

CASTAGNETTI, C. et al. Venous blood lactate evaluation in equine neonatal intensive care. Theriogenology, v.73, n.3, p.343357, 2010. Available from: < https://www.ncbi.nlm.nih.gov/ pubmed/19962183>. Accessed: Nov. 13, 2019. doi: 10.1016 / j.theriogenology.2009.09.018.

CHAFFIN, M.K. et al. Diagnostic assessment of Foals with Colic. In: Annual Convention of the American Association of Equine Practitioners, 1999, Albuquerque, United States of America. Proceedings... Albuquerque: AAEP, 1999. p.235-242. Online. Available from: $<$ http://citeseerx.ist.psu.edu/viewdoc/download?d $\mathrm{oi}=10.1 .1 .500 .1279 \& \mathrm{rep}=\mathrm{rep} 1 \&>$. Accessed: Jun. 24, 2019.

CRUZ, R. K. S. et al. Electrolyte, blood gas and electrocardiographic profile of neonatal foals in the first 48 hours of life. Acta Scientiae Veterinariae. v.43, p.1321-1327, 2015. Available from: <http:// www.ufrgs.br/actavet/43/PUB\%201321>. Accessed: Nov. 13, 2019.

GRINDEM, C.B. et al. Peritoneal fluid values from healthy foals. Equine Veterinary Journal, v.25, n.5, p.359-361, 1990. Available from: <https://beva.onlinelibrary.wiley.com/doi/ abs/10.1111/j.2042-3306. 1990.tb04290.x?sid=nlm\%3Apubmed $>$. Accessed: Nov. 13, 2019. doi: 10.1111/j.2042-3306.1990. tb04290.x.

HARVEY, J. W. Veterinary Hematology: A Diagnostic Guide and Color Atlas. St. Louis: Elsevier/Saunders, 2012. 
HUGLES, J.; BARDELL, B. Determination of reference intervals for equine arterial blood-gas, acid-base and electrolyte analyses. Veterinary Anesthesia and Analgesia, v.46, n.6, p.765-771, 2019. Available from: <https://www.vaajournal.org/article/ S1467-2987(19)30141-2/fulltext>. Accessed: Nov. 13, 2019. doi: 10.1016/j.vaa.2019.04.015.

KANEKO, J. J.; BRUSS, M. L. Bioquímica Clínica de Animais Domésticos. San Diego: Academic Press, 1997.

MEYER, D. J. et al. Medicina de laboratório veterinária: interpretação e diagnóstico. São Paulo: Roca, 1995.

NAPPERT, G. et al. Atresia coli in 7 foals (1964-1990). Equine Veterinary Journal, v.24, p.57-60, 1992. Available from: < https://onlinelibrary.wiley.com/doi/abs/10.1111/j.2042-3306.1992. tb04790.x>. Accessed: Jun. 24, 2019. doi: 10.1111/j.20423306.1992.tb04790.x.

SCHNEIDER, J.E. et al. Repair of congenital atresia of the colon in a foal. Journal of Equine Veterinary Science, v.1, p.121-126,
1981. Available from: <https://www.sciencedirecttype=pdf $>$. Accessed: Jun. 24, 2019.

VAN DER GAAG, I. et al. Intestinal atresia and stenosis in animals: A Report of 34 Cases. Veterinary Pathology, v.17, p.565574, 1980. Available from: < https://journals.sagepub.com/doi/abs /10.1177/030098588001700505>. Accessed: Jun. 24, 2019. doi: $10.1177 / 030098588001700505$.

VATISTAS, N.J. et al. Surgical treatment for colic in the foal (67 cases): 1980-1992. Equine Veterinary Journal, v.28, n.2, p.139145, 1996. Available from: <https://onlinelibrary.wiley.com/doi/ abs/10.1111/j.2042-3306.1996.tb01606.x?sid=nlm\%3Apubmed $>$. Accessed: Jun. 24, 2019. doi: 10.1111/j.2042-3306.1996. tb01606.x.

YOUNG, R.L. et al. Atresia coli in the foal: a review of six cases. Equine Veterinary Journal, v.1, n. 24, p. 60-62, 1992. Available from: <https://onlinelibrary.wiley.com/doi/abs/10. Accessed: Jun. $24,2019$. 